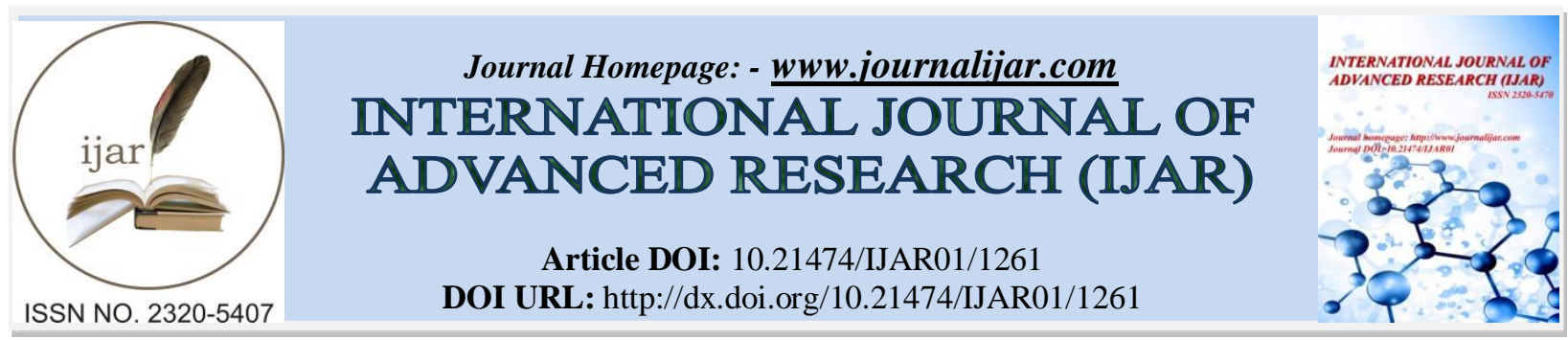

RESEARCH ARTICLE

\title{
CONSUMPTION OF FRESH LEAF OF TERMINALIA ARJUNA AND LEAF - COCOON RATIO OF INDIAN TASAR SILK WORM ANTHERAEA MYLITTA DRURY
}

\author{
Amulya Kumar Dash ${ }^{1}$, Urbasi Rani Jena ${ }^{2}$ and Bhaskar Behera ${ }^{3}$ \\ 1. Deptt. of Zoology, Siddheswar College, Amarda Rd., Balasore - 756030, Odisha, India \\ 2. Deptt. of Zoology, Nilgiri College, Nilgiri, Balasore - 756020, Odisha, India \\ 3. P. G. Deptt. of Biosc. \& Biotech., F. M. University, Vyasa Vihar, Balasore-756019, Odisha, India
}

\section{Manuscript Info}

Manuscript History

Received: 12 June 2016

Final Accepted: 13 July 2016

Published: August 2016

Key words:-

Cocoon, instar, ratio, consumption,

Antheraea mylitta, food plant, leaf

\section{Abstract}

The Indian tasar silk worm Antheraea mylitta Drury is polyphagous in nature as it feeds on different types of food plants. But one of the suitable food plants is Arjun ( Terminalia arjuna) which is adjudged as its primary food plant. In the recent study, the amount of fresh leaf consumption during the entire larval period was determined instar wise. It was noticed that the amount of leaf consumption gradually increased with progress of each stage of instars and was much higher during 5th instar. Finally the ratio of consumed leaf in each instar and for the formation of one cocoon was determined which was $136.31 \mathrm{~g}: 1$

Copy Right, IJAR, 2016,. All rights reserved.

\section{Introduction:-}

With regard to the production of cocoons and raw silk, the nutritional factor of the silk worm is very much important. Thus the proper selection of food plant is of paramount importance ( Hamamura, 1959 and Hamamura et al, 1962 ) especially for the tasar silk worm. Indian tasar silk worm Antheraea mylitta Drury usually feeds on a number of food plants although Terminalia ariuna is of primary importance. Several literatures are available on nutrition of Bombyx mori Linn. (Legay, 1958; Horie, 1962 \& Ito, 1967 ), Philosamia ricini Hutt (Kapil, 1963, 1967; Poonia, 1978 ) and other Lepidopterous larvae (Evans, 1939 ). Some information are available on consumption of Paropsis atomaria (Carne, 1966 ) Pseudoplusia includens (Kogan, 1974 ) Poecilocerus pictus (Delvi and Pandian, 1972 ) and Camulla pellucida ( Misra, 1962). Dash (2013) studied the energetics of A. mylitta and Jena et al(2015) reported the effect of food plants and altitude on growth of larva of A. mylitta. Effect of starvation stress on larvae of A. mylitta was earlier reported(Dash et al 1988). But till date no literature is traced regarding the amount of leaf consumption instar wise and leaf - cocoon ratio of A. mylitta feeding on Terminalia arjuna. So, this investigation was taken up.

\section{Materials and methods:-}

Initially twenty number of healthy hatchlings of same age were selected at random from a buffer stock and were reared on different branches of food plant, Terminalia arjuna. The branches were marked by different serial numbers which were taken for leaf consumption of larva. A cone shaped plastic sheet was fixed at the base of each branch of food plant in order to prevent the migration of larva to other branches. Prior to this all the leaves present in the selected branches were marked by different serial 
numbers and the area of each leaf was traced on different graph papers marking the serial number below each graph. Constant observation was kept on the larva released in each branch to detect the leaves consumed by the larva. Habitually the larva feeds on a leaf partially and then moves to another leaf for feeding as per its choice. In order to determine the amount of leaf consumed during each instar, the partially eaten leaves were plucked from the experimental branch. A similar sized leaf was taken from the branch of another identical plant matching the traced area. The difference between the weight of the total leaf and partially consumed leaf was determined gravimetrically to know the amount of actual leaf consumed.

Then the ratio of consumed leaf for each instar was determined. The percentage of leaf consumption at each instar out of the total consumption during larval life was calculated in order to estimate instar wise rearing capacity of $T$. arjuna food plant of different ages. The obtained data was correlated with the information earlier reported by Nayak et al(1998).

Table 1: Consumption of the amount $(\overline{\mathrm{x}} \pm \mathrm{SD})$ of fresh leaf of Terminalia arjuna by different instars of Antheraea mylitta Drury

\begin{tabular}{|l|l|l|l|l|l|c|l|}
\hline Instar & $\mathrm{N}$ & $\begin{array}{l}\text { Amount of } \\
\text { fresh } \\
\text { consumed (g) }\end{array}$ & $\begin{array}{l}\text { leaf } \\
\text { Leaf }- \text { instar } \\
\text { ratio }\end{array}$ & $\begin{array}{l}\text { \% of total } \\
\text { consumed } \\
\text { leaf of the } \\
\text { entire larval } \\
\text { period }\end{array}$ & $\begin{array}{l}\text { Number of } \\
\text { silk worms } \\
\text { to be } \\
\text { brushed in a } \\
3 \text { year aged } \\
\text { plant }\end{array}$ & $\begin{array}{l}\text { Number of } \\
\text { silk worms } \\
\text { to be } \\
\text { brushed in a } \\
4 \text { year aged } \\
\text { plant }\end{array}$ & $\begin{array}{l}\text { Number of } \\
\text { silk worms } \\
\text { to } \\
\text { brushed in a } \\
5 \text { year aged } \\
\text { plant }\end{array}$ \\
\hline First & 20 & $0.23 \pm 0.07$ & $0.23: 1$ & 0.17 & 1821 & 4064 & 7358 \\
\hline Second & 20 & $1.07 \pm 0.11$ & $1.07: 1$ & 0.78 & 391 & 873 & 1581 \\
\hline Third & 20 & $3.18 \pm 0.76$ & $3.18: 1$ & 2.34 & 131 & 294 & 532 \\
\hline Fourth & 20 & $14.31 \pm 1.31$ & $14.31: 1$ & 10.52 & 29 & 65 & 118 \\
\hline Fifth & 20 & $117.52 \pm 4.29$ & $117.52: 1$ & 86.41 & 3 & 8 & 14 \\
\hline
\end{tabular}

\section{Result and discussion:-}

The amount(g) of fresh leaf of the food plant Terminalia arjuna consumed by the first, second, third and fourth instar larva was $0.23 \pm 0.07,1.07 \pm 0.11,3.18 \pm 0.76$ and $14.31 \pm 1.31$ respectively( Table 1 ). But the fifth instar larva consumed $117.52 \pm 4.29 \mathrm{~g}$ of fresh leaf. This shows a sudden rise of consumption of food during fifth instar stage. The leaf - instar ratio of first, second, third and fourth instar stage was $0.23: 1$, $1.07: 1,3.18: 1$ and $14.31: 1$ respectively (Table 1 ) while the ratio was too high in fifth instar stage i. e. $117.52: 1$.

The percentage of leaf consumed during first, second, third and fourth instar was $0.17 \%, 0.78 \%, 2.34 \%$, and $10.52 \%$ of the total leaf consumed during the entire larval period. But only during fifth instar stage the percentage of leaf consumed was $86.41 \%$ of the total consumed leaf during larval life span (Table 1 ). It was observed that almost 6 times of the amount of leaf consumed during first to fourth instar was only consumed by fifth instar. Thus fifth instar stage appeared to be the most crucial stage for better silk production. So, utmost care should be taken during rearing operation

during this period.

After calculation of the amount of consumed leaf by different instars of larva of A. mylitta, it was established that in a three year aged Terminalia arjuna food plant 1821, 391, 131, 29 numbers of first, second, third and fourth instar larva can be reared respectively, while only 3 numbers of fifth instar larva can spend the entire larval period in the same plant without facing any starvation stress ( Table 1 ).

In a four year aged food plant 4064, 873, 294 and 65 numbers of first, second, third and fourth instar larva of A. mylitta can be reared respectively. But only 8 numbers of fifth instar larva can be reared in the same food plant without facing starvation stress ( Table 1 ). 
Similarly in a five year aged $T$. arjuna food plant 7358, 1581, 532 and 118 numbers of first, second, third and fourth instar larva of A. mylitta can be reared safely, while only 14 numbers of fifth instar larva can be reared successfully until the completion of cocoon formation (Table 1 ).

It was calculated from Table 1 that $136.31 \mathrm{~g}$ of leaf is required for the completion of total larval period of A. mylitta. Since one healthy larva can produce one better cocoon at the end of termination of feeding period of the fifth instar larva, it was estimated that the ratio of one cocoon - leaf $(\mathrm{g})$ is $1: 136$. Basing on the cocoon-leaf ratio, it was observed that in a three year aged Terminalia arjuna food plant 3 cocoons can be procured, while in a four year aged food plant 8 and in a five year aged food plant 14 numbers of cocoons can be conveniently harvested. Besides, the present data also confirms that the frequent manual transfer of larvae from one food plant to other food plant from instar to instar after all leaves are exhausted, can be avoided to exclude the chance of physical stress on larvae and the chances of reduced raw silk yield.

The present research findings on A. mylitta show direct application in the field level where the larvae are reared under semi domesticated condition in open rearing field. The physical transfer of larvae from one food plant to another food plant becomes stressful for the silk insects (Dash et al, 1988 ). It also hampers the process of cocoon formation as well as the amount of yield of raw silk. The watch and ward necessary during rearing activities can be better handeled by fixing the number of larvae to be reared for the entire larval period in a particular plant. In order to confirm the real enhancement of silk productivity and other commercial aspects by applying these findings, further studies are suggested.

\section{References:-}

1. Carne, P. B. : Growth and food consumption during the larval stages of Paropsis atomaria (Coleoptera: Chrysomelidae ) Ent. Exp. Appl. 9 : $105-112$ ( 1966 ).

2. Dash, A. K.,S. Mishra, B. K. Nayak and M. C. Dash : Studies on effect of starvation stress on hatchlings of tasar silk insect Antheraea mylitta Drury. Annu. Rept. St. Seric. Res. Stn. Ori. 5: 42 - 44 (1988).

3. Dash A.K.: Bio energetic of larva of Antheraea mylitta. Bull. Ind. Acad. Seri. 17(1\&2) :73-82 (2013).

4. Delvi, M. R. and T. J. Pandian : Rates of feeding and assimilation in the grasshopper, Poecilocerus pictus. J. Insect Physiology, 18:1829-1843 (1972).

5. Evans, A. C. : The utilization of food by certain lepidopterous larvae. Trans. R. Ent. Sc. Lond., 89: $13-22$ ( 1939 ).

6. Hamamura, Y. : Food selection by silk worm larvae. Nature, 183 : 1746 -1747 (1959).

7. Hamamura, Y., K. Nayashiya, K. Naito, K. Matsura and J. Nishida : Food selection by silk worm larvae. Nature, $194: 754-756$ ( 1962 ).

8. Horie, Y.: Effects of various fractions of mulberry leaves on the feeding of the silk worm, Bombyx mori L. J. Sericult. Sci. Japan, 31 : 258 -264 ( 1962 ).

9. Ito, T. : Nutritional requirements of the silk worm, Bombyx mori L. Proc. Japan Acad. 43 : 57 -61 ( 1967 ).

10. Jena, L. K., A. K. Dash and B. Behera: Development of fifth instar female larva of Antheraea mylitta Drury ( Saturniidae) on different food plants at different altitudes during rainy season. Int. J. Sci. Res. 1 (B ): $36-38$ ( 2015 ).

11. Kapil, R. P.: Quantitative feeding of leaves of Philosomia ricini, Indian J. Entomol. 25 : 233 - 241 ( 1963 ).

12. Kapil, R.P. Effects of feeding different host plant on the growth of larvae and weight of cocoon of Philosomia ricini. Indian J. Entomol. 29:295-296 (1967).

13. Kogan, M. and D. Kope : Feeding and nutrition of insects associated with soyabeans, food intake, utilization and growth in the soyabean looper, Pseudoplusia includens. Ann. Entomol. Soc. Am. 67: 66-72 ( 1974 ).

14. Legay, J. M. : Recent advances in silk worm nutrition, A. Rev. Ent. 3: 75 - 86 ( 1958 ).

15. Misra, S. D. : Nutritional ecology of the clear - winged grasshopper, Camulla pellucida (Scudder ) ( Orthoptera : Acrididae ). Memoir Indian Museum, 14:87-171 ( 1962 ).

16. Nayak, B. K., A. K. Dash and N. Mohanty: Studies on growth and leaf yield of Asan (Terminalia alata) and Arjun ( Terminalia arjuna ) plants, the primary food plants of the tasar silk moth A. paphia Linn. and A. mylitta Drury. Bull. Ind. Acad. Seri. 2 ( 1 ): 44 - 48 ( 1998 ).

17. Poonia, F. S. : Studies on food utilization and rate of growth during the development stages of Eri silk worm, Philosomia ricini Hutt. (Lepidoptera:Saturniidae) Ind. J. Seri. 17: 48-60 ( 1978 ). 